\title{
The Impact of Corporate Governance on the Profitability of Insurance Firms in Syria
}

\author{
Souzan M. Kabbani ${ }^{1}$ \& Essam K. Zaneldin ${ }^{2}$ \\ ${ }^{1}$ Finance and Banking Department, College of Economics, Aleppo University, Aleppo, Syria \\ 2 Engineering Management Program, United Arab Emirates University, Al-Ain, United Arab Emirates \\ Correspondence: Souzan M. Kabbani, Finance and Banking Department, College of Economics, Aleppo University, \\ Aleppo, Syria.
}

Received: August 29, 2020

Accepted: November 2, 2020

Online Published: January 11, 2021

doi:10.5430/ijfr.v12n2p150

URL: https://doi.org/10.5430/ijfr.v12n2p150

\begin{abstract}
This paper investigates the impact of corporate governance on the profitability of joint-stock insurance firms listed and unlisted in the 'Damascus Securities Exchange' in Syria during the period from 2013 to 2019. Research data was collected from the financial reports of the insurance firms and the reports of the 'Syrian Insurance Supervisory Commission' and the 'Syrian Commission of Financial Markets and Securities'. A model was then proposed for corporate governance of insurance firms. The proposed model considers eight independent variables (board size, independence of board members, non-executive board members, solvency, ownership, firm size, firm age, and joint-stock) and two dependent variables (return on equity and return on shares). Multi regression analysis for the 'Balanced Panel Data' is used to analyze the relationship between the governance of insurance firms and their profitability. The analysis of the results revealed that some independent variables (such as firm size, ownership, and none-executive members) have a significant positive impact on the return on equity while the 'firm size' and 'ownership' independent variables have a significant positive impact on the return on shares. The 'solvency' variable has a significant negative impact on the return on equity and return on shares. On the other hand, the 'firm age' variable has a significant negative impact on the return on equity while the 'joint-stock' variable is considered statistically significant with a positive impact on the return on shares. It was also observed that the 'independence of board members' variable has no impact on the dependent variables.
\end{abstract}

Keywords: Syria, corporate governance, agency theory, Syrian insurance companies, return on shares, return on equity

\section{Introduction and Literature Review}

Corporate governance plays an important role for the proper functioning of organizations. The existence of corporate governance contributes to the legitimacy and credibility of the firm. However, the concept of corporate governance is not always well understood, particularly in emerging market and industries like the Syrian insurance sector. As reported by Rebeiz \& Salameh (2006), a consensual definition of corporate governance is the internal system of rules, practices, processes, and other contractual and organizational schemes by which a firm is directed and controlled. This control mechanism is established by the board of directors to ensure managerial accountability and financial reporting reliability. Corporate governance essentially involves balancing the interests of a firm's stakeholders, such as shareholders, management executives, customers, suppliers, the government, and the community. This is achieved by determining the duties and responsibilities of the board of directors and executive management of the company taking into account the protection of shareholders and the rights of stakeholders. In essence, the main purpose of an effective corporate governance system is to improve the performance levels and attract investments by having appropriate management practices and controls. These corporate governance practices are more likely to achieve broad measures of success in the future by eliminating or reducing cases of financial and administrative corruption and gaining the confidence of stakeholders (Pillai \& Al-Malkawi, 2017). Governance also provides protection to investors through its compliance with laws and ethical responsibilities and the commitment of all employees to these ethics. On the other hand, governance increases the level of confidence in firms, improves the level of transparency, and reduces the level of risk, which lead to a better business environment and stability (Alabdullah, 2016).

The separation between the owners of a firm and its managers has increased the agency problem since the cost of 
unsupervised management is believed to be high unless proper oversight is given to a separate and independent body representing the interests of shareholders. In essence, the firm's board of directors is an independent entity that has been given the stewardship of corporate governance with the power to monitor, control, and advise the senior management (Rebeiz \& Salameh, 2006). The role of the board of directors is to minimize agency costs arising from the separation of ownership and control, while preserving shareholder value (Rebeiz \& Salameh, 2006). Despite the fact that shareholders are removed from the operational activities of the firm, the first and most important priority of corporate governance is to ensure that shareholders receive adequate return on their investments; otherwise, the management team would operate without accountability to shareholder. Although corporate governance considers shareholders as paramount, the board of directors should also look after the interests of other constituencies such as employees, customers, suppliers, and the community.

In the past years, several firms suffered from bankruptcy and the insurance sector was not an exception (Constantin \& Clipici, 2016). Constantin \& Clipici (2016) discussed several cases of bankruptcy of insurance companies and presented a model for predicting and estimating the risk of bankruptcy of insurance companies. The most cited reason for these failures is often attributed to the absence of appropriate corporate governance mechanisms and, in particular, the lack of an independent boardroom configuration such as an insufficient number of outside and independent directors and the combination of the roles of the CEO and Chairman of the board of directors. When the boardroom is not independent from management, it may not be possible to avoid potential conflicts of interest between the managers (the agents) and the shareholders (the principals). One of the requirements of having an effective corporate governance system is that the majority of board members should be independent and non-executive members. Another important requirement is to have a dual governance structure where two board committees are formed: an executive committee and a supervisory committee. This is in addition to having more clear and detailed risk management procedures.

Syria is suffering from the consequence of the war that has started in 2011. Due to this war crisis, very limited number of investments were attracted to invest in the country, particularly in the insurance sector. The objective of this paper, therefore, is to investigate the impact of using corporate governance in the insurance industry in Syria. The main reason of focusing on Syrian insurance firms is that the insurance sector in Syria is still in its development stage and the main direction of the country is to rely on external investments during the rebuilding phase following the war. Therefore, the reform of corporate governance is necessary for developing countries (such as Syria) in order to attract investments and boost their economies. As globalization and risk management are considered challenges for corporate governance, attention has to be paid to the extent to which governance is applied to build a more transparent and stable financial system (Gericke, 2018). The concept of governance in insurance firms is, therefore, of particular importance as it protects the rights and interests of shareholders and policyholders by holding the members of the board of directors and senior management accountable for their actions. This is in addition to the level of transparency, independence, and accuracy of all disclosed information, as well as the extent of compliance with legal and regulatory legislations and requirements (IAIS, 2006; Geofry, 2018).

In essence, the primary goal of firms is to achieve the maximum possible profit while satisfying the interests of its stakeholders. Several research efforts focused on studying the effect of governance on the financial performance of organizations. These efforts concluded that governance promotes investment and generates higher profits for firms by increasing the access to capital and reducing potential risks (Oino \& Itan, 2018; Darkwah et al., 2016). On the other hand, corporate governance reduces corruption and helps in attracting local and foreign funding sources, which leads to the creation of new job opportunities (Tunay \& Yüksel, 2017). Abdoush (2017), for example, investigated the effect of corporate governance on the performance of UK insurance companies during the period from 2004 to 2013. Li et al. (2017) conducted a similar research to study the impact of corporate governance on the performance of life insurance companies in China using a questionnaire survey. The two studies revealed that governance reduces the agency problem, which is reflected in the performance and profitability of firms. In another study conducted by Petchsakulwong and Jansaku (2018) and Akeem et al. (2014), it was concluded that profitability is influenced by the size of the board of directors in a firm and by the percentage of external directors. The studies of Najjar (2012) and Feng (2017) revealed that corporate governance has in impact on the financial performance of firms as a result of the supervision and control made by shareholders, the degree of ownership concentration, and the independence of the board. The study of Carter et al. (2003) indicated that the number of board members is an important factor in the financial performance of the firm. Latif et al. (2014) and Demeke (2016) revealed that increasing the size of the board may lead to a diversity of experiences among board members, which in turn will reflect positively on the performance and profitability of firms, in addition to having a mixed ownership structure to achieve different goals. Habbash and Bajaher (2014) conducted a similar study and concluded that increasing the size of the board of 
directors may lead to problems related to coordination and communication between the members of the board, which in turn reduces the ability of the board to play its supervisory and oversight role and, thus, increase the agency problem. On the other hand, the studies of Black et al. (2016) and Dai et al. (2016) revealed that investors prefer firms that disclose their financial and non-financial information. The result of the study also indicated that firms that have good governance tend to prevent insiders from using internal private information for their own interests and adopt transparent standards in dealing with investors and shareholders. This will reduce firms' risks and raises the value of its shares in the market, which will be reflected in one way or another in the profitability of the firm.

More recently, Markonah et al. (2019) investigated the effect of corporate governance and premium growth on the performance of insurance companies in Indonesia during the period from 2011 to 2017 and concluded that applying corporate governance improves the growth of companies. Junaid et al. (2020) studied the relationship between corporate governance mechanisms and the performance of insurers in Pakistan using the data of listed insurers on the Pakistan Stock Exchange. The findings of this study indicated that board composition, ownership concentration, and executive compensation are the most influential internal mechanisms for the insurers' performance. The study revealed that executive directors usually work for their own benefits instead of company goals while non-executive directors are not involved in the daily operations and, therefore, cannot monitor the resources of the company. This is considered a common scenario in the case of developing countries because of inappropriate governance mechanisms. Likewise, Al-ahdal et al. (2020) examined the impact of corporate governance on the financial performance of Indian and Gulf Cooperation Council listed firms. The results of this research revealed that board accountability and audit committee have an insignificant impact on firms' performance while transparency and disclosure have an insignificant negative impact. The results also indicated that corporate governance practices and financial performance of Indian firms are better than Gulf countries. In another study, Koji et al. (2020) compared the performance difference between family and non-family firms in the Japanese manufacturing industry from the perspective of corporate governance using a sample size of 861 non-family and 551 family firms over the period from 2014 to 2018. The study indicated that both family and non-family firms differ significantly in terms of ownership structure, board structure, and firm performance and that family firms outperformed non-family firms.

As a matter of fact, several studies address corporate governance recently in developing countries (e.g., Yousef, 2014; Okoye et al., 2016; El-Chaarani, 2014; Mardnly et al., 2018). However, very few research efforts were found in the literature related to corporate governance in Syria, particularly related to its implementation in insurance firms. Despite the importance of previous research efforts, these studies did not consider risk management as an important mechanism in a governance model. In this study, the relationship between governance and profitability in a developing country (Syria) is investigated. This research investigates the impact of applying governance on the profitability of twelve joint-stock Syrian insurance firms during the period from 2013 to 2019. This study introduces an empirical algorithm to measure the impact of using governance on the profitability of insurance firms in Syria. Multi regression analysis is used to analyze the relationship between the governance of insurance firms and profitability. The governance was measured using a set of internal mechanisms while profitability was measured using the return on equity (ROE) and the return on shares (ROS) indicators. A background summary about the insurance in Syria was first presented followed by the research methodology. The collected data was then analyzed and the results were presented. The novelty of this study is that it the first of its kind that introduces an empirical algorithm to measure the impact of using governance on the profitability of insurance firms in Syria. This research also considers risk management as one of the most important governance mechanisms. An effective risk management system (including strategies, operations, and reporting procedures) is very essential in insurance firms and deemed necessary to define, monitor, manage, and report risks. The results of this research are expected to provide an insight into the impact of governance on the profitability of insurance firms in developing markets.

\section{Background on Insurance in Syria}

In 2004, the Syrian government created an independent Insurance Supervisory Commission to control the insurance sector in the country. The main responsibility of this authority is to supervise insurance firms in order to protect the rights of shareholders, management executives, customers, suppliers, investors, the government, the community, and other parties. This authority also monitors the businesses of insurance and re-insurance firms. A decree was then issued in 2005 by the Syrian Commission of Financial Markets and Securities (SISC) to regulate the insurance sector in Syria. The decree also allows the insurance private sector to practice insurance business after it was exclusively manipulated by one public-sector organization. This decree provided an appropriate and healthy environment for insurance firms to practice their business in Syria and helped in developing the insurance sector dramatically.

The insurance sector in Syria consists of a reinsurance firm, a public insurance firm, and twelve private joint-stock 
insurance firms. Among the twelve private insurance firms, six are listed in the Damascus Stock Exchange (DSE) and two are Islamic (Takaful) insurance firms. The total capital for the joint-stock insurance firms reached around US\$28 million in 2018 and the total number of insurance deals for the listed firms reached 2004. The trading volume for insurance companies reached around 1.6 million shares in 2018 (DSE, 2018). In 2007, the SISC issued another decree for companies to start practicing governance in Syria. This decree is mainly derived from the Organization for Economic Cooperation and Development (OECD) standards and was amended in 2018 (SISC, 2018). This amendment was an important step for developing the insurance sector and promoting the transparency and credibility in the insurance market in the country. It was also a positive step to expand the scope of applying governance, not only to joint-stock firms but also to public firms. However, the two decrees did not refer to the importance of having an independent actuarial in every insurance firm.

\section{Research Methodology}

Research data was collected from the reports of the 'Syrian Insurance Supervisory Commission' and the corporate governance reports issued by the 'Syrian Commission of Financial Markets and Securities (SCFMS).' This data was collected for all joint-stock insurance firms in Syria (twelve firms in total). However, since the insurance market in Syria is relatively new, this resulted in collecting limited data due to the limited number of available insurance firms. This is in addition to the similarity in the performance of these firms as a result of the low competition.

The study considered balanced cross-sectional time-series data using the 'Balanced Panel Data' to merge the data of listed and unlisted insurance firms in Syria during the period from 2013 to 2019. This study also analyzed the financial statements data of insurance firms. In 2017, OECD issued guidelines related to the principles of governance in insurance firms. These guidelines apply to any insurance and reinsurance firm and are considered as a reference for all insurance firms that are members in the OECD. The guidelines provide benefits to the insured parties, the shareholders, and the policyholders in the case of Takaful firms (OECD, 2017). Governance in Takaful firms is very similar to the traditional insurance; however, the ultimate goal of Islamic corporate governance is to protect the interests and rights of all stakeholders while adhering to the principles of Islam Sharia. In essence, it makes the principles of 'Islam Sharia' part of the corporate governance (Al-Nemer, 2016).

This study suggests a model based on the principles of the OECD for corporate governance of insurance firms and the model presented by Kashif and Sardar (2008). The proposed model considers eight independent variables: board size, independence, non-executive board members, solvency, ownership, firm size, firm age, and joint-stock in addition to two dependent variable: return on equity and return on shares. The model reflects the characteristics of insurance firms through a set of governance mechanisms, in addition to some control and random dummy variables. As such, the proposed model introduces the following equation for insurance corporate governance (ICG):

$$
\text { Insurance Corporate Governance }(\mathrm{ICG})=\mathrm{INT}+\mathrm{CV}+\mathrm{DV}
$$

Where,

INT represents the set of independent variables that represent the internal mechanisms. The independent variables include the size of the firm board of directors, independence, solvency, non-executive board members, and the ownership of shareholder.

CV represents the control variables. It includes the age of the firm and its size.

DV represents the dummy variables.

Figure 1 shows the 'ICG' independent variables and the 'profitability' dependent variables. As shown in the figure, the 'ICG' independent variables are eight while the 'profitability' dependent variables are two. The following subsections elaborates in detail on these independent and dependent variables.

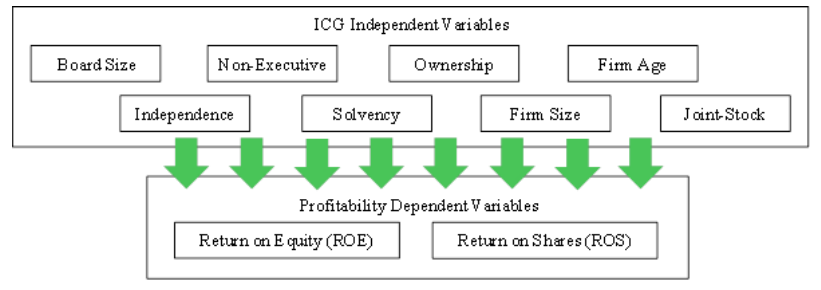

Figure 1. Independent and dependent variables of the proposed model 


\subsection{ICG Independent Variables}

The ICG dependent variables used in this research are composed of eight variables: board size, independence of board members, non-executive board members, solvency, Ownership, firm size, firm age, and joint-stock. A brief description of each of these variables is presented in the following parts of this subsection.

\subsubsection{Board Size (BSIZE)}

The firm bylaws identify the size of the board of directors for a firm, the duration of their term, and their membership expiration date. According to the agency theory, when the board size increases, communication problems increase and the firm faces coordination problems among the directors (Cremers \& Sepe, 2018). Moreover, when the board size increases, the problem of information inconsistencies increases, which leads to conflicts of interest and increases costs (Nugroho \& Agustia, 2017). However, a larger board size will have a positive impact, as it will provide a variety of knowledge, backgrounds, and experiences. This is in addition to the fact that a large number of managers increases the supervisory capacity and improves the effectiveness of the firm's decision-making and risk management (Geofry, 2018).

\subsubsection{Independence and Non-executive Board Members}

The board of directors is composed of three main categories: 1) executive director, 2) independent directors, and 3) the non-executive directors. The structure of the board of directors also differs from one country to another. In the United States of America, for example, firms have one board of directors (one-tier) while in Germany, firms have two levels of board of directors (two-tier), the executive board of directors (consists of executive members) and the supervisory board (includes non-executive members who represent shareholders and employees). In some other countries, such as France, firms can choose a one-tier or a two-tier board to improve governance (Brealey et al., 2011). The degree of independence of the board of directors is represented by the presence of non-executive external members. This plays an important role in monitoring administrative activities and improving the efficiency of strategies. According to the agency theory, independent members are more objective in making decisions and have greater incentives to encourage firms to disclose private information (Green, 2005). Governance principles recommend to have a sufficient number of independent and non-executives members in the board of directors of firms. The independence of the board of directors is measured by dividing the 'number of independent members' by the 'total number of the members in the board of directors'. Similarly, the non-executive measure in the board of directors is calculated by dividing the 'number of non-executive members' by the 'total number of the members of the board of directors.'

\subsubsection{Solvency}

The board of directors should be fully aware of the main risks associated with the firm operations and should have an appropriate policy to manage these risks. They should also make sure that the firm is carrying out appropriate and effective procedures for managing risks and that the risk management system is subjected to regular reviews. The board of directors should also maintain a sound and effective internal monitoring and control system to protect shareholders investments and firm assets (Sun et al., 2011). In essence, governance is considered directly responsible for managing risks and monitoring the integrity of its reports for the safety and effectiveness of corporate risk management. Solvency is considered an important factor to measure the ability of insurance firms to meet their obligations and, thus, face risks, which in turn will be reflected in the performance and profitability of firms. Solvency is measured by dividing the 'available total capital' over the 'required total capital'. The required capital consists of assets risk, underwriting risks, reinsurance risks, and life insurance risks while, according to certain weighting ratios, the available capital consists of the core capital and the additional capital. The core capital consists of the initial paid capital, declared reserves, and retained earnings after subtracting the losses and the decrease in mathematical and technical reserves while the additional capital includes the increase in the value of the investment. For insurance firms, when the margin of solvency is less than $75 \%$, the firm must inform the SISC of the corrective measures that it will take to raise its solvency margin to the required level. If the solvency margin falls below 50\%, the SISC has the right to appoint an authorized external advisor to manage the firm or cancel the license of the firm. If the solvency margin is between $50 \%$ and $75 \%$, the 'SISC' has the right to force the firm to take one or more of the following actions as it deems appropriate: increase the capital of the firm, set a plan to reduce costs, stop new public offerings of shares, and/or sell some of the firm's assets.

\subsubsection{Ownership}

Ownership structures are divided into two main categories: the 'dispersed ownership' and the 'concentrated ownership' (Hajer \& Anis, 2016). The 'dispersed ownership' indicates that there are a large number of shareholders 
own a small number of shares (e.g., Anglo-Saxon) while the 'concentrated ownership' refers to a small number of shareholders owning a large number of shares (Ozili \& Uadiale, 2017). In the latter, shareholders exercise more control and dominance such as the control and dominance of the bank or Family board control (Elbardan \& Kholeif, 2017). The majority of firms in developing countries (including Syria) usually fall under the 'concentrated ownership' category. Shareholders of such firms seek to maximize their wealth by maximizing the long-term value of the firm and increasing the level of firm performance (Tanc, 2015). However, this will negatively affect the smallholders' equity and their role in the firm. Therefore, the role of applying the principles of governance becomes essential to protect the rights of the minority and smallholders.

\subsubsection{Firm Size}

The 'Forbes Global 2000 Index' uses four measures to rank firms in terms of the size and fastest growing firms around the world. These four firm size measures are assets, sales, profit, and market value and the choice of these measures have different implications. If the firm size refers to the total resources, the total assets should be used while the total sales are more related to product market (Dang et al., 2017). Gonenc and Ursu (2018) found a stronger asset growth effect during crisis years relative to other years. This is because investors in developing markets do not have enough access to information in addition to the fact that the agency problems are higher because of insufficient legal protection and weaker dissemination of information. Since this study was conducted during crisis year in Syria, the study followed the recommendation of Gonenc and Ursu (2018) and used the rate of asset growth to measure the firm size. The studies indicated that large firms have a higher level of governance as compared to small firms (Madhani, 2016; Ilaboya \& Ohiokha, 2016). This is because large firms have more experience and higher incentives to increase the level of governance in order to gain the confidence of investors (Goddard et al., 2004). However, the study of Arora and Sharma (2016) revealed a negative relationship of the firm size with its performance since the bureaucracy increases when the size of the firm increases and this may cause severe resistance to change, which leads to a decrease in the level of profitability. In general, the effect of the firm size on the profitability of firms is not quite clear.

\subsubsection{Firm Age}

The age of the firm represents the number of years since its inception. It is quite established in the literature that a firm 'age' has a positive impact on its profitability (Kramaric, 2017). In essence, individuals and investors have more confidence in firms that have been in the market for a long time and that have good performance and reputation. On the other hand, older firms absorb most of their initial expenses in the first years of their establishment, making them well established and financially sound (Kramaric, 2017).

\subsubsection{Joint-Stock}

Since there are two types of listed and unlisted joint-stock firms in Syria, it was necessary to distinguish between them to know the impact of each type. If the firm is a listed firm, it is given a value of one while a zero value is given for unlisted firms.

\subsection{Profitability Dependent Variables}

There is a difference between the concept of profit and that of profitability. Profit is the difference between revenue and costs while profitability is an indicator of the efficiency and performance of the firm (Majid et al., 2012). Profitability reflects the firm's success and its ability to improve the adequacy of its capital. It is used as a measure of profit that the firm earns over a specific period of time and the ability of the firm to achieve the return required by owners and shareholders (Boadi et al., 2013). The profitability dependent variables used in this study are the return on equity and return on shares.

\subsubsection{Return on Equity (ROE)}

One of the main goals of firms is to achieve attractive profits for shareholders and investors. The ROE indicator measures the return that shareholders achieve on their funds invested in the capital of the firm. If the value of this indicator is high, it indicates the efficiency of the investment and operating decisions of the firm. The ROE is measured by dividing the 'firm's net income' by the 'value of the shareholders' equity' (Siminica et al., 2012).

\subsubsection{Return on Shares (ROS)}

The ROS is an indicator that measures the firms' performance and tells investors and shareholders whether the firm has a strong standing in the market or not. It also indicates the potential growth rate of shareholders' equity. The ROS is measured by 'dividing the firm's net income' by its 'average number of shares' (IAS, 2009). Based on the previous discussion and theoretical background, the proposed hypotheses can be summarized as follows: 
H1: indicates that there is significant effect of corporate governance on the return on equity (ROE) indicator.

$\mathrm{H} 2$ : indicates that there is significant effect of corporate governance on the return on shares (ROS) indicator.

The following multivariate regression models have been used to test the proposed hypotheses, after including all the variables in the equations:

$$
\begin{aligned}
& \mathrm{ROE}_{\mathrm{i}, \mathrm{t}}=\alpha+\text { BSize }{ }_{1} i t+\text { Independence }{ }_{2} i t+\text { Solvency } i t+\text { Non-Executive } i t+{ }_{\text {Size }}{ }_{5} i t+\text { Age }{ }_{6} i t+ \\
& \text { Ownership it }+ \text { Joint-Stock } \quad \text { it }+ \text { it } \\
& \text { Ownership } \quad \text { it }+ \text { Joint-Stock } \quad \text { sit }+ \text { it }
\end{aligned}
$$

Where,

$\mathrm{ROEi} ; \mathrm{t}$ and ROSi; denote the profitability indicators of firm $\mathrm{i}$ at a time $\mathrm{t}$.

BSize, Independence, Solvency, Non-Executive, Size, Age, Ownership, and Joint-Stock represent all governance mechanisms for insurance firms and control and dummy variables.

The 'Panel Data' regression model is based on a set of assumptions that ensure the validity of using the model in the prediction process. Before performing data analysis and estimating study models, the validity of the data and its suitability for testing the hypotheses is verified by performing the 'normality of errors', 'Durbin Watson', 'linearity of independent variables', and 'VIF' tests (Baltagi, 2005). Results of these verification tests are as follows:

\subsection{Normality of the Errors Test}

The results of the 'Jarque-Bera' test indicated that the residuals are naturally distributed for the multiple regression model, where the value of the 'Jarque-Bera' test was insignificant at a level greater than 0.05 .

\subsubsection{Autocorrelation}

The results of the 'Durbin Watson (D-W)' test showed that there is no autocorrelation of the residuals as the values were close to 2 (Agung, 2009).

\subsubsection{Linear Relationship}

The 'linearity of independent variables' test indicated that the points of random errors follow a linear relationship, which indicates the linearity of random errors as illustrated in the Q-Q chart of Figure 2 (plotted using 'EViews' software).

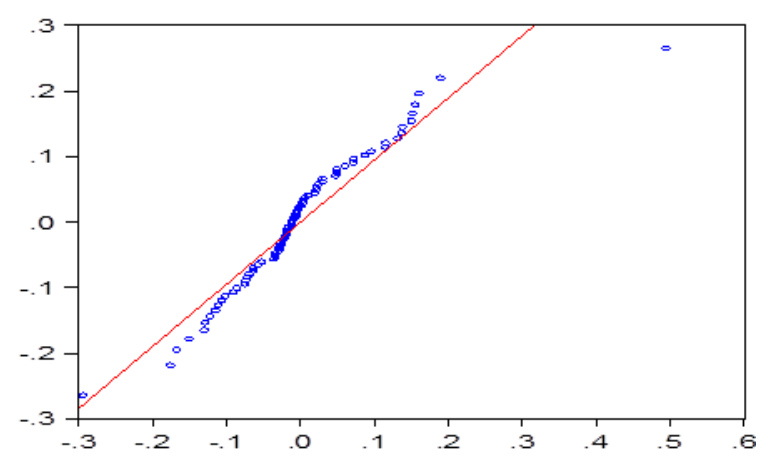

Figure 2. Normal Q-Q plot of Housman test using 'EViews' software

\subsubsection{Multicollinearity}

The results of the VIF test showed that all variables did not exceed 5 except the "BSize" and, therefore, this variable was excluded from the model and the correlation matrix has also confirmed that result (Akinwande et al., 2015). This indicates that the findings of this study are reliable and strong.

\section{Results and Discussion}

\subsection{Discussion of Variables}

The data of this research was analyzed and the results revealed that the size of the board of directors in Syrian 
insurance firms is relatively small. The board size ranges between 5 and 7 members in listed firms while it is between 3 and 9 members for unlisted firms. It was also found that all board members of listed firms are independent and non-executives. This indicates the role of the SCFMS to ensure that listed firms comply with the principles of corporate governance. On the other hand, most of the board members of unlisted firms are also non-executives. However, unlisted firms did not maintain the required minimum level of independence, which is one third of the board size.

Despite the availability of bylaws to limit the percentage of ownership of banks in the shares of firms, the analysis of the results indicated that there is some dominance of banks over the ownership of the shares of Syrian insurance firms. This is in addition to the concentration of ownership, where the shares of largeholders represent $60 \%$ of the total value of the firm shares. This reduces the agency problem since the largeholders have the ability to direct and control administrative activities in the firm, particularly in developed countries like Syria. However, the rights of smallholders should be protected by ensuring their participation in the firm's general assemblies and voting and their ability to access firm documents and files in addition to allowing them to prosecute the members of the firm's board of directors. In 2008, the SISC issued a solvency system for Syrian insurance firms, where each firm is obliged to maintain the minimum solvency margin of $150 \%$. In this study, it was found that the solvency of all insurance firms are way higher than the minimum required percentage. It is worth mentioning that maintaining very high solvency rates deprives firms from investing and making profits. To overcome this issue, it is better that firms use actuaries in pricing and identifying risks instead of depending on non-specialists.

\subsection{The Impact of Corporate Governance on the Profitability of Insurance Firms}

In essence, the income of insurance firms comes from insurance premiums, interests on bank deposits, and the increase in exchange rates while the net profit in Syrian insurance firms is the profit after taxes and includes any differences in exchange rates and does not include the surplus of policyholders in 'Takaful' insurance firms. The rate of asset growth has been used to measure the size of the firm, where the asset growth rate $=100 *$ (total assets for the current year - total assets for the previous year)/total assets for the previous year. In this research, 'EViews' is used as a tool to perform statistical data analysis and generate forecasts. Table 1 shows the 'EViews' estimated values of the coefficients of the fixed and random effects model in panel data regression of 'ICG' variables and 'ROE' variables for Syrian insurance firms.

Table 1. Results of fixed and random effects

\begin{tabular}{llllc}
\hline \multirow{2}{*}{ Variables } & \multicolumn{3}{l}{ Random Effect } & Fixed Effect \\
\cline { 2 - 5 } & T-Statistic & P-Value & T-Statistic & P-Value \\
\hline Constant (C) & -1.508224 & 0.1364 & 0.489334 & 0.6264 \\
Size & 4.370252 & 0.0000 & 3.280503 & 0.0017 \\
Solvency & -2.641207 & 0.0104 & -2.721297 & 0.0085 \\
Age & -2.017574 & 0.0478 & -2.801268 & 0.0069 \\
Non-Executive & 2.072388 & 0.0423 & 0.920662 & 0.3610 \\
Independence & -0.756904 & 0.4519 & -0.974483 & 0.3338 \\
Ownership & 2.687118 & 0.0092 & 1.929488 & 0.0585 \\
Joint-Stock & 1.954668 & 0.0550 & 1.727299 & 0.0893 \\
\hline Prob(F-statistic) & 0.000587 & & 0.000002 & \\
\hline
\end{tabular}

Table 1 reports the regression results of the dependent variable (ROE) using the 'Panel Least Method'. The results showed a significant impact of both models and, therefore, 'Housman Test' was selected to determine the final model appropriate for the data of this study (Housman, 1978). If the fixed effects model is the appropriate model, an additional test (called 'Waled Test') should be performed while no further tests are required if the random effects model is found to be the appropriate model (Green, 2003). The results of 'Housman Test' shown in Table 2, indicated that the P-value is greater than 0.05 and, therefore, the 'null hypothesis' was not rejected. The 'null hypothesis' indicates that that the random effects model is the appropriate model (Guilkey \& Murphy, 1993). 
Table 2. Housman test results

\begin{tabular}{llll}
\hline Variable & Chi-Sq & Chi-Sq. d.f & P-value \\
\hline ROE & 9.496 & 6 & 0.1476 \\
ROS & 10.053 & 6 & 0.1224 \\
\hline
\end{tabular}

The Prob(F-statistic) value shown in Table 3 indicates the significance of the model. Table 3 also shows that the coefficient of determination (R-squared) value is 0.3202 , which indicates that the independent variables (size, solvency, age, ownership, and non-executive) in the model represent around $32 \%$ of the variation in the ROE variable. This means that the regression curve is good to describe the relationship between this indicator and the independent variables.

Table 3. Random effect regression analysis of the effect of ICG variables on ROE

\begin{tabular}{lrrrl}
\hline Variable & Coefficient & Std. Error & \multicolumn{1}{l}{ t-Statistic } & Prob. \\
\hline Constant (C) & -0.287083 & 0.190345 & -1.508224 & 0.1364 \\
\hline Size & 0.221526 & 0.050690 & 4.370252 & 0.0000 \\
\hline Solvency & -0.730174 & 0.276455 & -2.641207 & 0.0104 \\
\hline Age & -0.559918 & 0.277520 & -2.017574 & 0.0478 \\
\hline Non-Executive & 0.354109 & 0.170870 & 2.072388 & 0.0423 \\
\hline Independence & -0.026292 & 0.034737 & -0.756904 & 0.4519 \\
\hline Ownership & 0.319553 & 0.118920 & 2.687118 & 0.0092 \\
\hline Joint-Stock & 0.044243 & 0.022635 & 1.954668 & 0.0550 \\
\hline R-squared: 0.320218 & & & Adjusted R-squared: 0.2458 \\
\hline Prob(F-statistic): 0.000587 & & & \\
\hline
\end{tabular}

Table 4 shows the estimates values of the coefficients of the fixed and random effects model in 'Panel Data Regression' of 'ICG' variables and 'ROS' variable in Syrian insurance firms.

Table 4. Results of fixed and random effects

\begin{tabular}{lllll}
\hline & Random Effect & & Fixed Effect \\
\hline P-value & T-Statistic & P-value & T-Statistic & Variable \\
\hline 0.4260 & -0.801658 & 0.960304 & 0.3405 & Constant (C) \\
\hline 0.0006 & 3.626587 & 4.106566 & 0.0001 & Size \\
\hline 0.0005 & -3.715445 & -3.261770 & 0.0018 & Solvency \\
\hline 0.0061 & 2.844619 & 0.862354 & 0.3917 & Age \\
\hline 0.6406 & -0.469314 & -1.344478 & 0.1835 & Non-Executive \\
\hline 0.0661 & -1.872279 & -1.265307 & 0.2103 & Independence \\
\hline 0.0285 & 2.245413 & 3.625159 & 0.0006 & Ownership \\
\hline 0.1311 & 1.531207 & 2.111621 & 0.0386 & Joint-Stock \\
\hline
\end{tabular}

The results in the table showed a significant impact of both models while the results of 'Housman Test' shown in Table 2 indicated a P-Value greater than 0.05 and, therefore, the 'null hypothesis' was not rejected. Table 4 reports 
the regression results of 'ROS' dependent variable using 'Panel Least Method'. Table 5, on the other hand, shows the $\operatorname{Prob}(\mathrm{F}-$-statistic) value as 0.01 with a level of significance of $5 \%$, which indicates the significance of the model and that it is valid for use. Table 5 also shows that the coefficient of determination (R-squared) value is 0.303 , which indicates that the independent variables (size, solvency, ownership, joint-stock) in the model represent around 30\% of the variation in the ROS variable, which means that the regression curve is good to describe the relationship between this indicator and the independent variables.

Table 5. Random effect regression analysis of the effect of ICG variables on ROS

\begin{tabular}{lllll}
\hline Variable & Coefficient & Std. Error & t-Statistic & Prob. \\
\hline Constant (C) & 65.25714 & 67.95468 & 0.960304 & 0.3405 \\
\hline Size & 64.23444 & 15.64189 & 4.106566 & 0.0001 \\
\hline Solvency & -280.5035 & 85.99733 & -3.261770 & 0.0018 \\
\hline Age & 1.447503 & 1.678549 & 0.862354 & 0.3917 \\
\hline Non-Executive & -90.65215 & 67.42553 & -1.344478 & 0.1835 \\
\hline Independence & -13.58543 & 10.73687 & -1.265307 & 0.2103 \\
\hline Ownership & 132.1949 & 36.46596 & 3.625159 & 0.0006 \\
\hline Joint-Stock & 14.66879 & 6.946697 & 2.111621 & 0.0386 \\
\hline R-squared: 0.302662 & & & Adjusted R-squared: 0.226391 \\
\hline Prob(F-statistic): 0.001170 & & & \\
\hline
\end{tabular}

\section{Concluding Remarks and Recommendations}

The results of this study revealed that the firm 'size' has a significant positive impact on the 'ROE' and 'ROS'. This indicates that the larger the size of the firm, the more the incentive will be for firms to apply governance in order to gain the confidence of investors and stakeholders, which will in turn improve profitability. This is consistent with the results of Madhani (2016) and Ilaboya \& Ohiokha (2016). Similar to the firm 'size' effect, the 'ownership' has a significant positive impact on the 'ROE' and 'ROS' as shareholders strive to maximize their wealth by increasing the level of firm performance through their oversight role on management performance. The results also indicated that there is a positive effect of the number of the board of directors 'non-executive members' on the 'ROS', which indicates that the more the number of non-executive members, the higher the level of governance will be. This will also improve the profitability of the firm as a result of raising the level of confidence and reducing agency problems. Similarly, 'listed firms' have a positive impact on the 'ROS' as they adhere to the principles of governance better than unlisted firms. This is due to the fact that listed firms are subjected to bilateral supervision from the SISC and SCFMS government authorities. On the other hand, 'solvency' has a significant negative impact on the 'ROE' and 'ROS'. This indicates that the higher the solvency rate, the lower the 'ROE' and 'ROS'. This is because firms tend to retain funds to deal with possible potential risks and, therefore, they lose the opportunity of using these funds for potential investments. Firm 'age' has a negative impact on the 'ROE', as older firms may have more disputes, which affects the profitability of these firms. The results also revealed that there is no impact of the 'independence' of the members of the board of directors on both the 'ROE' and 'ROS'. This is because of the migration of some members from the board of directors as a result of the 2011 war crisis in the country. This is in addition to the relatively small size of the board of directors in Syrian insurance firms, which has partially constituted to the imbalance in the structures of firm's boards of directors and affected their independence.

Based on the findings of this study, the authors suggest the following recommendations:

Despite the importance of the insurance sector globally, this sector did not get the required level of attention and care in Syria. The authors of this study believe that Syrian insurance firms should promote an openness policy based on transparency and collaboration with international insurance markets.

Since there are discrepancies between the decisions and bylaws of the SISC and the SCFMS resulted in a gap in the application of governance principles, the authors recommend that the two authorities unify their decisions and bylaws. This will also enhance and strengthen the ability of authorities to supervise and monitor firms. 
A code for corporate governance for the Syrian insurance market should be issued to make the concept of governance clear and understandable to foreign investors and stakeholders.

Insurance firms in Syria should also invest part of their funds in investment subsidiaries and investment funds. They should also make sure that they use actuaries to estimate risks and prices of their insurance products instead of raising the solvency margin to very high levels, which may lead to losing potential investment opportunities.

The rights of smallholders should be protected by ensuring their participation in the firm's general assemblies and voting and their ability to access firm documents and files in addition to allowing them to prosecute the members of the firm's board of directors.

Very limited research efforts were found in the literature related to investigating corporate governance in Syria, particularly for insurance firms. This study addressed this issue and provided an in-depth insight regarding this matter. The findings and recommendations of this study can be useful for the SISC and the SCFMS to suggest new regulations and policies to develop the corporate governance in the insurance sector. The study also used the solvency margin to measure risk management as one of the most important internal governance mechanisms. The results of the study can be generalized to developing countries that are undergoing the same conditions as those of Syria. As a possible future extension to the present study, the authors will investigate the impact of implementing governance on the profitability of insurance firms after a couple of years. This is important since current insurance firms in Syria are relatively new, this is in addition to the fact that these firms were not able to highlight the impact of all variables and their impact during the period following the Syrian crisis. On the other hand, better results can be obtained by considering the channels of institutional monitoring which affect corporate debt policy. Therefore, governance mechanisms interacting with institutional monitoring should be further investigated.

\section{References}

Abdoush, T. (2017). Corporate governance, firm performance and efficiency: Three empirical analyses of the UK insurance industry. PhD Thesis, Faculty of Business, University of Southampton. Retrieved from https://www.researchgate.net/publication/316185742_Corporate_governance_firm_performance_and_efficienc y_three_empirical_analyses_of_the_UK_insurance_industry

Agung, A. G. (2009). Time series data analysis using eviews. Singapore: John Wiley \& Sons, Inc.

Akeem, L., Tere, K. E., Temitope, O. A., \& Feyitimi, O. (2014). Measuring impact of corporate governance on the performance of national insurance company. International Journal of Economics Commerce and Management, II(11), 1-17.

Akinwande, M., Dikko, H., \& Samson, A. (2015). Variance inflation factor: As a condition for the inclusion of suppressor variable(s) in regression analysis. Open Journal of Statistics, 5, 754-767. Retrieved from https://www.scirp.org/pdf/OJS_2015122416050944.pdf

Alabdullah, T. T. Y. (2016). Corporate governance from the perspective of the past and the present and the need to fill an international gap. Risk Governance and Control: Financial Markets and Institutions, 6(4), 96-101.

Al-ahdala, W. M., Alsamhib, M. H., Tabashc, M. I., \& Farhand, N. H. S. (2020). The impact of corporate governance on financial performance of Indian and GCC listed firms: an empirical investigation. Research in International Business and Finance, 51, 1-13.

Al-Nemer, H. (2016). Governance of insurance firms, a comparative study between the Saudi and the international insurance. International Journal of Academic Research and Reflection, 4(8), 58-59.

Arora, A., \& Sharma, C. (2016). Corporate governance and firm performance in developing countries: evidence from India. Corp Governance, 16, 420-436.

Baltagi, H. B. (2005). Econometric analysis of panel data. England: John Wiley \& Sons, Inc.

Black, B., Khanna, V., Kim, W., \& Yurtogl, B. (2016). Corporate governance indices and construct validity. Corporate Governance: An International Review, 25(6), 397-410.

Boadi, E., Antwi, S., \& Lartey, V. (2013). Determinants of profitability of insurance firms in Ghana. International Journal of Business and Social Research, 3(3), 43-50.

Brealey, R., Myers, S., \& Allen, F. (2011). Principles of corporate finance. USA: McGraw-Hill.

Carter, A. D., Simkins, J. B., \& Simpson, W. G. (2003). Corporate governance board diversity and firm value. The Financial Review, 38(1), 33-53. https://doi.org/10.1111/1540-6288.00034 
Constantin, D., \& Clipici, E. (2016). A new model for estimating the risk of bankruptcy of the insurance companies based on the artificial neural networks. Proceedings of the 16th International Multidisciplinary Scientific GeoConference SGEM, 1 Sofia, 3-10.

Cremers, M., \& Sepe, S. (2018). Institutional investors, corporate governance, and firm value. Seattle University Law Review, 41, 388-405.

Dai, L., Fu, R., Kang, J., \& Lee, I. (2016). Corporate governance and the profitability of insider trading. Journal of Corporate Finance, 40, 235-253.

Dang, C. D., Li, F., \& Yang, C. (2018). Measuring firm size in empirical corporate finance. Journal of Banking and Finance, 86, 159-176.

Darkwah, K. A., Asare-Kumi, A. A., Baidoo, K. I., \& Nortey, E. (2016). Profitability of insurance companies in Ghana: Panel co-integration and causality. British Journal of Economics Management and Trade, 14(3), 1-11.

Demeke, A. (2016). Corporate governance mechanisms and firm performance: the case of Ethiopian insurance industry. Journal of Investment and Management, 5(2), 6-16.

DSE. (2018). Syrian insurance companies data. Retrieved from http://www.dse.gov.sy/index.php?lang=en

Elbardan, H., \& Kholeif, A. (2017). Enterprise resource planning, corporate governance and internal auditing. Switzerland: Springer.

El-Chaarani, H. (2014). The Impact of corporate governance on the performance of Lebanese banks. The International Journal of Business and Finance Research, 8(5), 35-46.

Feng Y. (2017). The effectiveness of corporate governance mechanisms and leadership structure. Ph.D. Thesis, The Erasmus University Rotterdam, Netherlands.

Geofry, A. (2018). Comparative study of the impact of compliance with corporate governance regulations and internal governance mechanisms on financial performance of listed firms in Africa. PhD Thesis, The Open University Faculty of Business and Law, UK.

Gericke, R. C. (2018). Corporate governance and risk management in financial institutions. Switzerland: Springer International Publishing.

Goddard, J., Molyneux, P., \& Wilson, J. (2004). The profitability of European banks: Cross sectional and dynamic panel analysis. The Manchester School, 72(3), 363-381.

Gonenc, H., \& Ursu, S. (2018). The Asset growth effect and investor protection in emerging markets: the role of the global financial crisis emerging markets. Finance \& Trade, 54, 491-507.

Green, S. (2005). Sarbanes-Oxley and the board of directors: Techniques and best practices for corporate governance. Canada: John Wiley \& Sons, Inc.

Green, W. (2003). Econometric analysis. New Jersey: Prentice Hall, Inc.

Guilkey, D., \& Murphy, J. (1993). Estimation and testing in the random effects Probit model. Journal of Econometrics, 59(3), 301-317.

Habbash, M., \& Bajaher, M. S. (2014). An empirical analysis of the impact of board structure on the performance of large Saudi firms. The Business Review, 22(1), 152-158.

Hajer, Ch., \& Anis, J. (2016). Analysis of the impact of governance on bank performance: Case of commercial Tunisian banks. Journal of the Knowledge Economy, 9, 871-895. Retrieved from https://link.springer.com/content/pdf/10.1007/s13132-016-0376-6.pdf

Housman, G. A. (1978). Specification tests in econometrics. Econometrica, 46(6), 1251-1271. https://doi.org/10.2307/1913827

IAIS. (2006). Issues in regulation and supervision of Takaful (Islamic insurance). International Association of Insurance Supervisors. Switzerland, August 2006. Retrieved from https://www.iaisweb.org/page/supervisory-material/issuespapers/file/34274/issues-in-regulation-and-supervis

IAS 33. (2009). Earnings per share. Retrieved from https://www.iasplus.com/en/standards/ias/ias33

Ilaboya, J. O., \& Ohiokha, F. I. (2016). Firm age, size and profitability dynamics: A test of learning by doing and structural inertia hypotheses. Business and Management Research, 5(1), 29-39. 
Junaid, M., Xue1, Y., Syed, M. W., Ziaullah, M., \& Riffat, N. (2020). Corporate governance mechanism and performance of insurers in Pakistan. Green Finance, 2(3), 243-262.

Kashif, R., \& Sardar, M. N. I. (2008). Corporate governance and firm value: Econometric modelling and analysis of emerging and developed financial markets. Bingley, UK: International Business and Management Series 23, Emerald Group Publishing.

Koji, K., Adhikary, B. K., \& Tram, L. (2020). Corporate governance and firm performance: a comparative analysis between listed family and non-family firms in Japan. Journal of Risk and Financial Management, 13(215), $1-20$.

Kramaric, T., Miletic, M., \& Pavic, I. (2017). Profitability determinants of insurance markets in selected central and eastern European countries. International Journal of Economic Sciences, VI(2), 100-123.

Latif, B., Sabir, H., Saleem, H., \& Ali, A. (2014). The effects of corporate governance on firm financial performance: A study of family and non-family owned firms in Pakistan. Research Journal of Finance and Accounting, 5(17), 75-89.

Li, H., Zhang, H., Tsai, S., \& Qiu, A. (2017). China's insurance regulatory reform, corporate governance behavior and insurers' governance effectiveness. International Journal of Environmental Research and Public Health, 14(1238), 1-14.

Madhani, P. M. (2016). Firm size, corporate governance and disclosure practices: Interrelations. SCMS Journal of Indian Management, 13(2), 17-39.

Majid, A., Al-Nu'aimatand, S., \& Qabajeh, M. (2012). The relationship between the ROA, ROE and ROI ratios with Jordanian insurance public companies market share prices. International Journal of Humanities and Social Science, 2(11), 115-120.

Mardnly, Z., Mouselli, S., \& Abdulraouf, R. (2018). Corporate governance and firm performance: An empirical evidence from Syria. International Journal of Islamic and Middle Eastern Finance and Management, 11(1), 591-607.

Markonah Markonah, M., Sudiro, A., Surachman, \& Rahayu, M. (2019). The effect of corporate governance and premium growth on the performance of insurance companies in Indonesia. European Research Studies Journal, XXII(2), 367-383.

Najjar, J. N. (2012). The impact of corporate governance on the insurance firm's performance in Bahrain. International Journal of Learning and Development, 2(2), 2164-4063.

Nugroho, W., \& Agustia, D. (2017). Corporate governance, tax avoidance, and firm value. Afebi Accounting Review, 2(2), 161-175.

OECD. (2017). OECD guidelines on insurer governance.

Oino, I., \& Itan, M. (2018). Impact of corporate governance on banks financial performance. Journal of Business Management and Economics, 1-9. https://doi.org/10.15520/jbme.v6i08.2262

Okoye, L. U., Evbuomwan, G., Achugamonu, O., \& Araghan, I. (2016). Impact of corporate governance on the profitability of the Nigerian banking sector. ESUT Journal of Accountancy, 7(1), 281-292.

Ozili, P. K., \& Uadiale, O. (2017). Ownership concentration and bank profitability. Future Business Journal, 3, 159-171.

Petchsakulwong, P., \& Jansaku, N. (2018). Board of directors and profitability ratio of Thai non-life insurers. Kasetsart Journal of Social Sciences, 39(1), 122-128.

Pillai, R., \& Al-Malkawi, H. N. (2017). On the relationship between corporate governance and firm performance. Research in International Business and Finance, 44, 394-410.

Rebeiz, K. S., \& Salameh, Z. (2006). Relationship between governance structure and financial performance in construction. Journal of Management in Engineering, 22(1), 20-26.

Siminica, M., Circiumaru, D., \& Simion, D. M. (2012). The correlation between the return on assets and the measures of financial balance for Romanian companies. International Journal of Mathematical Models and Methods in Applied Sciences, 6(2), 249-256. 
SISC. (2018). Governance guide in insurance and reinsurance firms and joint-stock insurance services providers. Retrieved from http://www.sisc.sy/Laws/122.htm/Ar

Sun, W., Stewart, J., \& Pollard, D. (2011). Corporate governance and the global financial crisis. Cambridge, UK: University of Cambridge Press.

Tanc, A. (2015). Corporate governance principles introduced by the capital markets board of Turkey and an investigation about internal audit in companies listed on Bursa Istanbul. Journal of Modern Accounting and Auditing, 11(3), 150-158.

Tunay, K. B., \& Yüksel, S. (2017). The Relationship between corporate governance and foreign ownership of the banks in developing countries. Contaduría Y Administración, 62, 1627-1642.

Yousef, H. M. E. (2016). The impact of corporate governance on the profitability of the listed companies in Jordan over the period from 2010 to 2014. European Journal of Business and Management, 8(23), 143-163.

\section{Copyrights}

Copyright for this article is retained by the author(s), with first publication rights granted to the journal.

This is an open-access article distributed under the terms and conditions of the Creative Commons Attribution license (http://creativecommons.org/licenses/by/4.0/). 